乳癌患者血漿中 matrix metalloproteinase 扔よび tissue inhibitor of metalloproteinase の測定意義の検討

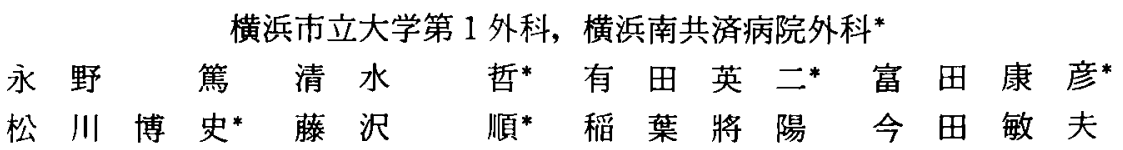

術前乳癌32症例を対象に，血漿中MMP-1．2，3，9およびTIMP-1，2を one step sandwich EIA 法にて测定し, その臨床的意義について健常女性50例の対照群と比較し 検討した.両群の平均值の比較では, MMP-1, MMP-3は差がなかったが,MMP-2, MMP. 9は乳癌群において低值であった $(\mathrm{p}=0.0033, \mathrm{p}=0.044)$ 。また, TIMP-1も乳癌群で有 意に低值であった $(\mathrm{p}<0.0001)$. そこで MMP と TIMP の量的バランスを反映すると考 えられる, MNP の濃度合計を TIMP の濃度合計で除した MMPs/TIMPs 濃度比を算 出し, 両群を比較検討した結果, 乳癌群は $0.857 \pm 0.261$, 健常群は $0.776 \pm 0.182 て ゙$, 乳 癌群で有意に高值であった。さらに乳癌群のTIMP-1はリンパ管侵襲度に負の相関を示 し, MMPS/TIMPs 濃度比はリンパ管侵埥度に正相関した。 以上より乳癌患者の血槳に おいて, TIMP-1およびMMPs/TIMPs は乳癌のリンパ管侵䶘度を反映する可能性が示 唆された。

索引用語: breast cancer, MMP, TIMP, MMPs/TIMPs 濃度比

\section{緒 言}

近年, 癌の浸潤・転移に matrix metalloproteinase (以下 MMP) の数種類のファミリーが関与することが 証明されている゙12). また tissue inhibitor of metalloproteinase (以下 TIMP) は活性型 MMPに結合し不 活化することによって，MMPの働きを特異的に阻害 することが知られている゙!。これまでに乳癌において も, MMP および TIMPの免疫組織化学染色や組織培 養液中の定量が検討され，乳癌組織中では, TIMP-1が 滅少していると報告されているが4，今回われわれは 乳癌患者の血中 MMP およびTIMP を測定し，その 臨床的意義について検討した。

\section{対象および方法}

対象は1995年 6 月から12月までに, 横浜南共済病院 外科において, 術前に血中 MMPs およびTIMPs を測 定した乳癌手術症例32例（以下乳癌群）である. 平均 年齢は51歳で, TNM 分類の進行度は Stage I が19例, Stage II が10例, Stage IIIaが3例であった.コント ロールは40歳から60歳の健常女性50例（以下健常群）

1997年 4 月17日受付 1997 年 7 月24日採用
とした。

測定項目は MNP-1，2、3、9および TIMP-1，2であ る. 測定方法は，入院時に採取した血清を $-40^{\circ} \mathrm{C} に て$ 1 ないし 2 日間保存した後に one step sandwich enzyme immuno-assay 法にて発色させ, 吸光度より 検量線を用いて血清濃度 $(\mathrm{ng} / \mathrm{ml})$ を求めた。ただし， MMP-9は血獎を検体とし，MMP-2およびTIMP-1は 測定感度の問題より，それぞれ10倍希釈，41倍希釈に て測定した. sample 量は MIMP.1, 2, 9は50 $\mu 1$, MMP.

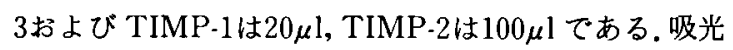
度の波長は MMP-1，2，9およびTIMP-1は492nm， MMP-3およびTIMP-2は450nmである。また検体の sample decay の問題に関しては, 各項目とも前実験の

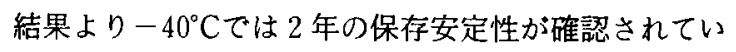
3 .

検討方法としては, 各測定項目の平均値を乳癌群と 健常群の 2 群間で比較した。また乳癌群のNNPS は cut off 值以上を陽性, TIMPs は cut off 値以下を陽性 とし, 乳癌群の MMP-1，2，3，9および TIMP-1，2の 陽性率をもとめた。さらに血漿中での MMP と TIMP のバランスを総合的に反映させるために, NIMP-1, 2, 
3, 9合計の総濃度を TIMP-1，2合計の総濃度で除した MMPs/TIMPs 濃度比を算出し検討した。さらに MMPs, TIMPs の測定值と臨床病理所見との関連性 について検討した. 検討した病理組織学的因子は, 腫 瘍径, リンパ節転移度, 組織型, リンパ管侵㢣度, 血 管侵裂度, 組織波及度, 核異型度, Estrogen receptor の8 項目である.

有意差検定は平均値の比較は Student-t 検定を用 い, 相関については, 偏相関係数を求め, Bartlett の検 定を行った。いずれの検定も $\mathrm{p}<0.05$ 有意差ありと した.

\section{結 果}

1) MMPs と TIMPs $の$ 平均值

乳癌群と健常群における MMP の平均値を比較す

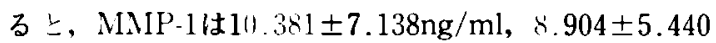
$\mathrm{ng} / \mathrm{ml}$, MNIP.2は490.594 $\pm 112.463 \mathrm{ng} / \mathrm{ml}, 553.4 \pm$ $74.850 \mathrm{ng} / \mathrm{ml}$, MMP-3は30.156 $\pm 20.034 \mathrm{ng} / \mathrm{ml}$, $35.850 \pm 16.786 \mathrm{ng} / \mathrm{ml}$, MIMP-96 $\$ 28.367 \pm 17.507 \mathrm{ng} /$ $\mathrm{ml}, 35.520 \pm 13.577 \mathrm{ng} / \mathrm{ml}$ と, MMP-1と MMP-3は両
群間で差はなかったが, M.MP.2と MMP-9は, 乳癌群 の方が健常群よりも有意に低値であった（ $\mathrm{p}=0.0032$, $\mathbf{p}=0.044 ＼mathrm{~ （ F i g . ~ 1) . ~ 一 方, ~ T I M P を 比 較 す る と, ~}$

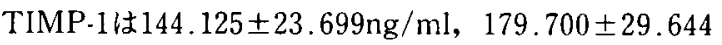
$\mathrm{ng} / \mathrm{ml}$, TIMP-2は65.594 $\pm 15.965 \mathrm{ng} / \mathrm{ml}, 54.420 \pm$ $16.504 \mathrm{ng} / \mathrm{ml}$ と, TIMP-1は乳癌群が健常群よりも有 意に低值であったが $(\mathrm{p}<0.0001)$, TIMIP-2は乳癌群が 健常群よりも有意に高値であった（ $p=0.0033 ） （$ Fig. 2).

\section{2) MMPs と TIMPs の cut off 值}

健常群の測定值より算出設定した MMPs の上限値 (mean $\pm 2 S D$ ) は, NMP-1: 19.7ng/ml, MMP-2 : 703.1ng/ml, MMP-3:69.4ng/ml, MMP-9:62.6ng/ $\mathrm{ml}$ で, TIMPs の下限値 (mean-2SD) は TIMP-1 : $120.4 \mathrm{ng} / \mathrm{ml}$, TIMP-2: $21.4 \mathrm{ng} / \mathrm{ml}$ であり，それらを cut off 值とした。また健常群の濃度比より算出した

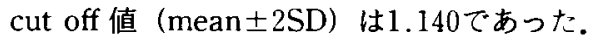

3）MMPs と TIMPs の陽性率

MMPs の陽性率をもとめると, MMP.1 : $12.9 \%$,

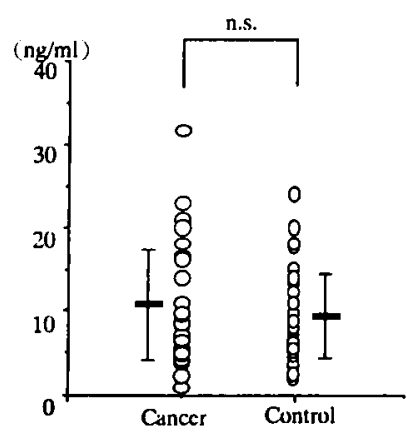

MMP-1

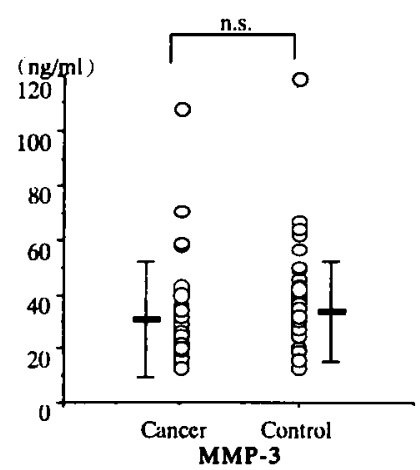

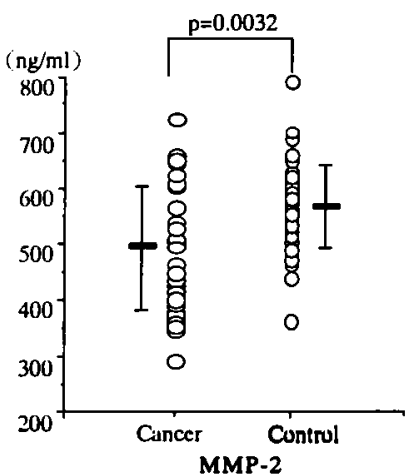

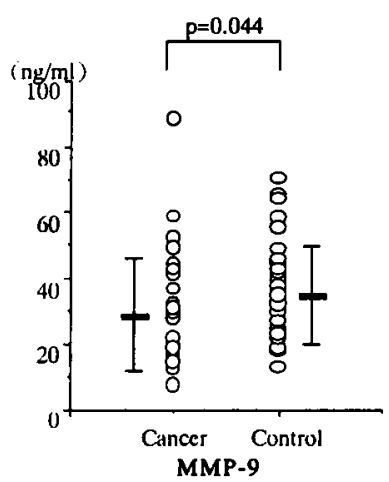

Fig. 1 Comparison of plasma MMPs levels in two groups (patient group, control group) $\mathrm{p}$ value: Student-t test 
MMP-2:3.1\%, MMP-3:3.1\%, MMP-9:3.1\%で あった。 TIMPs の陽性率は, TIMP.1は15.6\%と高率 であった。しかし TIMP-2は下限值以下を示すものは なかった (Table 1).

\section{4) MMPs/TIMPs 濃度比}

両群の濃度比を比較すると, 乳癌群は $0.857 \pm 0.261$, 健常群は0.776士0.182で, 乳癌群が有意に高かった ( $\mathrm{p}=0.0342)$ (Fig. 3)。乳癌群のうち MMPs/TIMPs

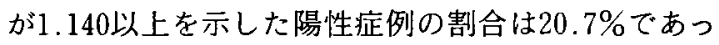
た.

5）MMP およびTIMP と臨床病理学的因子の関連 性

乳癌群の MMPs 扝よびTIMPs と臨床病理学的因 子の関連は, MMPs と TIMP-2は諸因子と相関しな かったが，TIMP-1はリンパ管侵襲度と負の相関を示 した $(\mathrm{p}=0.047)$.また MMPs/TIMPs 濃度比はリン パ管侵襲度と正の相関を示した $(\mathrm{p}=0.048)$ (Table 2).

\section{考察}

乳癌細胞が間質へ浸潤し，基底膜，血管壁およびリ ンパ管壁を破壊し脈管内に侵入し転移するためには, 間質成分の細胞外マトリックスの構成成分であるコ ラーゲン，ラミニン，フィブロネクチンなどを分解し なければならない.その分解作用を担うのが細胞外マ トリックス分解酵素つまり MMPである. 現在 MMP は少なくとも13種類のファミリーが同定されている が5), MMP-1，2，3，9は癌の浸潤・転移機構に関与す ると考えられている.その中の MMP-1は I， II， III， IV, VII，X型コラーゲンを基質とし, 間質線維を分解 し, 大腸癌や膀胱癌組織の浸潤先進部線維芽細胞で産 生が六進されているといわれている6!.また MMP-2, 9はゼラチン, プロテオグリカン, IV, V 型コラーゲン を基質とし，血管基底膜を分解するといわれてい る7)8).MMP-3もプロテオグリカン, フィプロネクチ ン，II，IV，IX型コラーゲンを基質とし，間質および 血管基底膜を分解するが，そればかりでなく, pro-

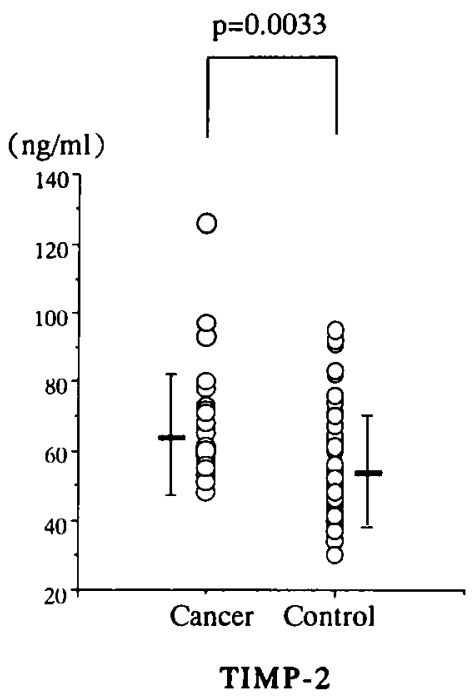

Fig. 2 Comparison of plasma TIMPs levels in two groups (patient group, control group)

p value : Student-t test

Table 1 Cut off values and positive rates of MMPs and TIMPs in patient group

\begin{tabular}{l|c|c|c|c|c|c}
\hline & MMP.1 & MMP-2 & MMP-3 & MMP-9 & TIMP-1 & TIMLP-2 \\
\hline Cut off value $(\mathrm{ng} / \mathrm{ml})$ & 19.7 & 703.1 & 69.4 & 62.6 & $120.4^{*}$ & $21.4^{*}$ \\
Positive rate $\left({ }^{\circ}{ }_{0}\right)$ & 12.9 & 3.1 & 3.1 & 3.1 & 15.6 & 0 \\
\hline
\end{tabular}

*lower limit 
MMP-1，2，9を活性化する働きがある779. MMP は癌 紐胞だけではなく宿主練胞のマクロファージ, 線維芽 細胞，血管内皮細胞，さらに末梢血の好中球によって も産生・分泌される7. 分泌された MMPはすへて不活 性型プロエンザイムであるが, プラスミンやカリクレ インなどのセリンプロテアーゼあるいは同じファミ リーであるMMP-3によって活性化を受ける9.こ札を 不活化するのが TIMP であり, MMPの基質分解の働 きを阻害し, 癌の間質への浸潤，脈管浸潤を抑制する といわれている3110). TIMPファミリーは現在 TIMP. 1，2，3の 3 種類が同定されており，分子量がそれぞれ $28 \mathrm{kD}$ の糖蛋白, $21.6 \mathrm{kD}$ の蛋白, $21 \mathrm{kD}$ の蛋白の遺伝子 がクローニングされている(10) 121. TIMP-1と TIMP-2 はそのアミノ酸配列の構造上，43\%の相同性を有する

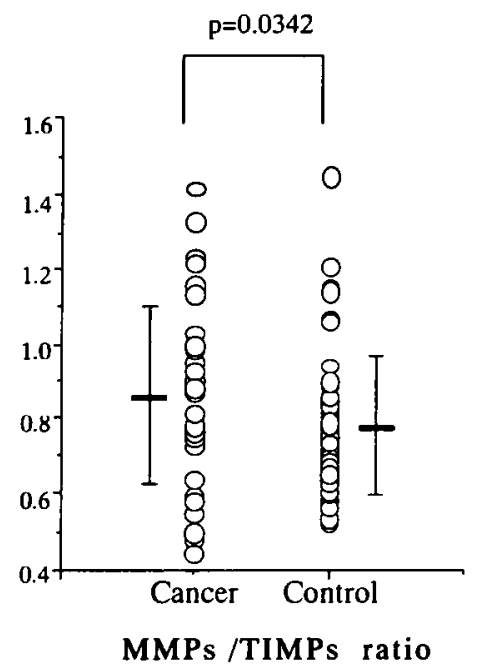

Fig. 3 Comparison of plasma MMPs/TIMPs ratio in two groups (patient group, control group)

p value: Student-t test
が，TIMP-1は間質コラゲナーゼである MMP-1を, TIMP-2はゼラチナーゼおよびIV型コラゲナーゼであ るMMP-2, 3,9を比較的特異的に阻害するといわれて (る ${ }^{13)}$.よって今回は TIMP-1, 2のみを検討対象とし， TIMP-3は除外した.これまで,動物実験腫湯や七トの 消化器癌を対象としたin situ hybridizationによる mRNAの検索や免疫組織化学染色, zymography 用いた酵素活性から MMP・TIMP の発現を評価した 報告がある(12)6144. そのなかでは転移性末分化型の大 腸癌や肺癌組織において, mRNA レベルで MMP-2の 高い発現が確かめられている6!. また七卜乳癌組織培 養液の MMPs，TIMPs の定量に関する報告4や高転 移型乳癌細胞株をラットの乳房脂肪組織に移植する と, 血漿中MMP-9が上昇するという報告がみられ $3^{(5)}$. しかしヒト乳癌の血整中の複数の MMP, TIMP を系統的に測定し検討した報告がないことより，われ われは今回の検討を行った。

その結果, 乳癌患者の未梢血において, MMP-1と MMP-3は健常人と差がなかったが, MMP-2と IIMP9は乳癌群で有意に低值であった，Zucker ら ${ }^{16}$ はヒト 乳癌患者血墏中で MMP.9の有意な上昇が認められる と報告しており，本検討と逆の結果を示している．し かし，その報告を背景因子別にみると， stage I 症例の MMP-9は control 群よりもむしろ低値で, stage II, III, IV 症例合計で有意な高値を示している. 本検討の 対象の多くが stage I であることを考虑すると, 対象 の進行度因子の構成分布の違いが結果の相違に反映し たと考えられた。以上のことから, stage I, II の早期 の乳癌症例においては, 血中の MMPsは必ずしも增 加しない可能性が考えられる.

今回の検討で, TIMP-1は乳癌群で低值を示したが, このことは岩田4の同様の報告から考えると，乳癌の 浸潤に対する宿主の防御反応としての TIMP-1の発現

Table 2 Correlation between MMPs, TIMPs and clinicopathological factors in patient group

\begin{tabular}{|c|c|c|c|c|c|c|c|c|}
\hline \multicolumn{2}{|c|}{ Characteristics (grade) } & MMP.1 & IIMP-2 & MMIP-3 & MMP.9 & TIMP.1 & TIMP.2 & MMPs/TIMPs \\
\hline Tumor size & $(\mathrm{T} 1, \mathrm{~T} 2, \mathrm{~T} 3, \mathrm{~T} 4)$ & - & - & - & - & - & - & - \\
\hline Lymph node metasta & $\mathrm{S}(\mathrm{n} 0, \mathrm{nl} \alpha, \mathrm{n} 1 \beta, \mathrm{n} 2)$ & - & $\ldots$ & -. & - & - & - & - \\
\hline Histological type & (pap, solid, sci, special) & - & - & - & - & - & - & - \\
\hline Lymphatic invasion & $(\operatorname{ly} 0, \operatorname{ly} 1, \operatorname{ly} 2)$ & - & - & - & - & 0.047 & - & 0.048 \\
\hline Vascular invasion & (v0, v1, v2) & - & - & - & - & - & - & - \\
\hline Infiltration & $(g, f, s)$ & - & - & - & - & - & - & - \\
\hline Nucler grade & (grade $1,2,3$ ) & - & - & - & - & - & - & - \\
\hline Estrogen receptor & $(+,-)$ & - & - & - & - & - & - & - \\
\hline
\end{tabular}

p value : Bartlett' test n.s. : not significant 
が早期から低下していることが示唆された。逆に TIMP-2が乳癌群で有意に高值であったことは奇異な 結果で，その原因に関しては明らかではない.しかし， TIMP-2の末梢血中の平均濃度は乳癌群, 健常群とも に TIMP-1の $1 \sim 3 \%$ 程度で, 測定の正確度に問題が

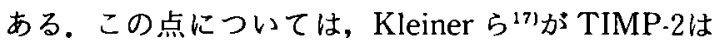
proMMP-2と複合体を形成しやすいので, 測定感度条 件の問題から結合型 TIMP-2の測定ができず, 測定可 能な TIMP-20絶対量が隇少するためであると報告し ている. 以上のことから, TIMP-2よりも TIMP-1の方 を測定する意義があると考えられた。

今回わ机わ机は MMPs/TIMPs 濃度比を一つのパ ラメーターとして検討した。 その理由は, 血中 MMP. 1，2，3，9の総量と TIMP-1，2の総量のバランスが個 体内の MMP 活性を反映すると考えたからである。そ の結果, 乳癌群の MMP.2と MMP.9の血中濃度は低下 していたにもかかわらず, MMPs/TIMPs 濃度比は健 常群よりも有意に高值を示し, リンパ管侵襲度に相関 した.これは血中 TIMP-1が隇少し, その反面 TIMP1が特異的に阻害するMMP-1はほぼ変化しないため, MMP-1/TIMP-1濃度比が上昇したためであると考え られた，従って，血中 MMPs/TIMPs 濃度比上昇の contributing factor は MMP-1/TIMP-1濃度比であ ク，なかでも血中 TIMP-1の減少が乳癌の間質浸潤の 進展に影響していると考えられ，術前に乳癌のリンパ 管侵襲を知る手段のひとつとして，血中の MMPs/ TIMPs と TIMP-1の測定, 特に TIMP-1の測定は意義 があると思われた。

\section{結 語}

乳癌患者では, 健常人よりも血中 MMPs/TIMPs 濃 度比が上昇し, TIMP-1は低下していた, 主に TIMP. 1が MMP 活性を左右し，乳癌のリンパ管侵襲に少な からず関与することが示唆された。

\section{文献}

1)赤木由人：肝転移に関するMatrix Metalloproteinase-9 (MMP-9)の)分泌能の研究一 ヌードマウス大腸癌自然肝転移モデルによる検 討. 日本大腸肛門病会誌 $47: 552-563,1994$

2）三浦一秀：大腸癌肝転移モデルにおけるMatrix Metalloproteinase 9 (MMP-9) および Tissue inhibitor of metalloproteinase 10 messenger RNA (mRNA)の発現と転移能に関する研究 in situ hybridization を用いて. 久留米医会誌 57 ： 892-904, 1994
3) Schultz RM, Silberman S, Persky B, et al: Inhibition by human amnion invasion and lung colonization by murine B16-F10 melanoma cells. Cancer Res 48: 5539-5545, 1988

4) 岩田広治：ヒト乳癌組織におけるマトリックスメ タロプロテイナーゼとそのインヒビターの解析. 名古屋市大医会誌 $45 ： 345-358,1994$

5) Imai K, Ohuchi E, Aoki T, et al: Membranetype matrix metalloproteinase 1 is a gelatinolytic enzyme and is secreted in a complex with tissue inhibitor of metalloproteinases 2. Cancer Res $56: 2707-2710,1996$

6) Poulsom $R$, Pignatelli $M$, Stetler-Stevenson WG, et al: Stromal expression of $7.2 \mathrm{kda}$ type IV collagenase (MMP-2) and TIMP.2 mRNAs in colorectal neoplasia. Am J Pathol 141 : 389396, 1992

7）中島元夫：転移における癌細胞と宿主細胞のマト リックスメタロプロテイナーゼの役割. 実験医 12 : $971-979,1994$

8) Woessner JF Jr: Matrix metalloproteinases and their inhibitors in connective tissue remodelling. FASEB J 5 : 2145-2154, 1991

9）永瀬秀明：プロテアーゼと生体機能. 東京化学同 人, 東京, 1993, p56-69

10) Stetler-Stevenson WG, Krutzsch HC, Liotta LA: Tissue inhibitor of metalloproteinase. J Biol Chem 264 : 1737t-17378, 1989

11) Docherty AJP, Lyons A, Smith BJ, et al: Sequence of human tissue inhibitor of metalloproteinase and its identity to erythroidpotentiating activity. Nature $318: 66-69,1985$

12) Yang TT, Hawkes SP: Role of the $21-\mathrm{kDa}$ protein TIMP. 3 in oncogenic transformation of cultured chicken embryo fibroblasts. Proc Natl Acad Sci USA 89 : 10676-10680, 1992

13) Howard EW, Bullen EC, Banda MJ : Preferential inhibitition of 72 - and $92-\mathrm{kDa}$ gelatinases by tissue inhibitor of metalloproteinases-2. J Biol (hem 226 : 13070-13075, 1991

14) Lu X. Levy $M$, Weinstein IB, et al: Immunological quantitation of levels of tissue inhibitor of metalloproteinase-1 in human colon cancer. Cancer Res $51: 6231-6235,1991$

15) Nakajima $M$, Welch $D R$, Wynn DM, et al: Serum and plasma $\mathrm{Mr}$ 92,000 progelatinase 
levels correlate with spontaneous metastasis of rat $13762 \mathrm{NF}$ mammary adenocarcinoma. Cancer Res $53: 5802-5807,1993$

16) Zucker S, Lysik RM, Zarrabi MH, et al: $\mathrm{Mr}$ 92,000 type IV collagenase is increased in plasma of patients with colon cancer and breast cancer. Cancer Res 53: 140 146, 1993

17) Kleiner DE Jr, Unsworth EJ. Krutzsch HC, et al: Higher-older complex formation between the 72-kilodalton type IV collagenase and tissue inhibitor of metalloproteinase-2. Biochemistry $31: 1655-1672,1992$

\title{
ANALYSES OF PLASMA NIETALLOPROTEINASES AND TISSUE INHIBITOR OF METALLOPROTEINASES IN PATIENTS WITH BREAST CANCER
}

\author{
Atsushi NAGANO, Satoru SHIMIZU*, Eiji ARITA*, Yasuhiko TOMITA*, \\ Hiroshi MATSUKAWA*, Jun FUJISAWA*, Masaaki INABA \\ and Toshio IMADA \\ Department of Surgery I, Yokohama City University, School of Medicine \\ *Department of Surgery, Yokohama Minami Kyousai Hospital
}

To evaluate the clinical significance of matrix metalloproteinases (MMPs) and tissue inhibitor of metalloproteinases (TIMPs). we analyzed plasma concentrations of MMP-1, 2, 3, 9 and TIMP-1, 2 in patients with breast cancer (patient group) using the enzyme immuno-assay technique. The average levels in 32 patients were compared with the levels of 50 healthy women (control group).

The average levels of all MINPs were no higher in the patient group than in the control group. On the contrary, the average level of TIMP-1 was significantly lower in the patient group than in the control group.

Thus, the total concentration of MMPs divided by the total concentration of TIMPs (MMPs/TIMPs ratio) was elevated in the patient group. Furthermore, the MMPs/TIMPs ratio correlated with the lymphatic permeation. These results suggest that the TIMP-1 and the MMPs/TIMPs ratio correlate with lymphatic permeation of breast cancer. 